\title{
Imam Shamsi Ali: Thoughts on Islam and Material Culture
}

Interviewed by Ashley Makar

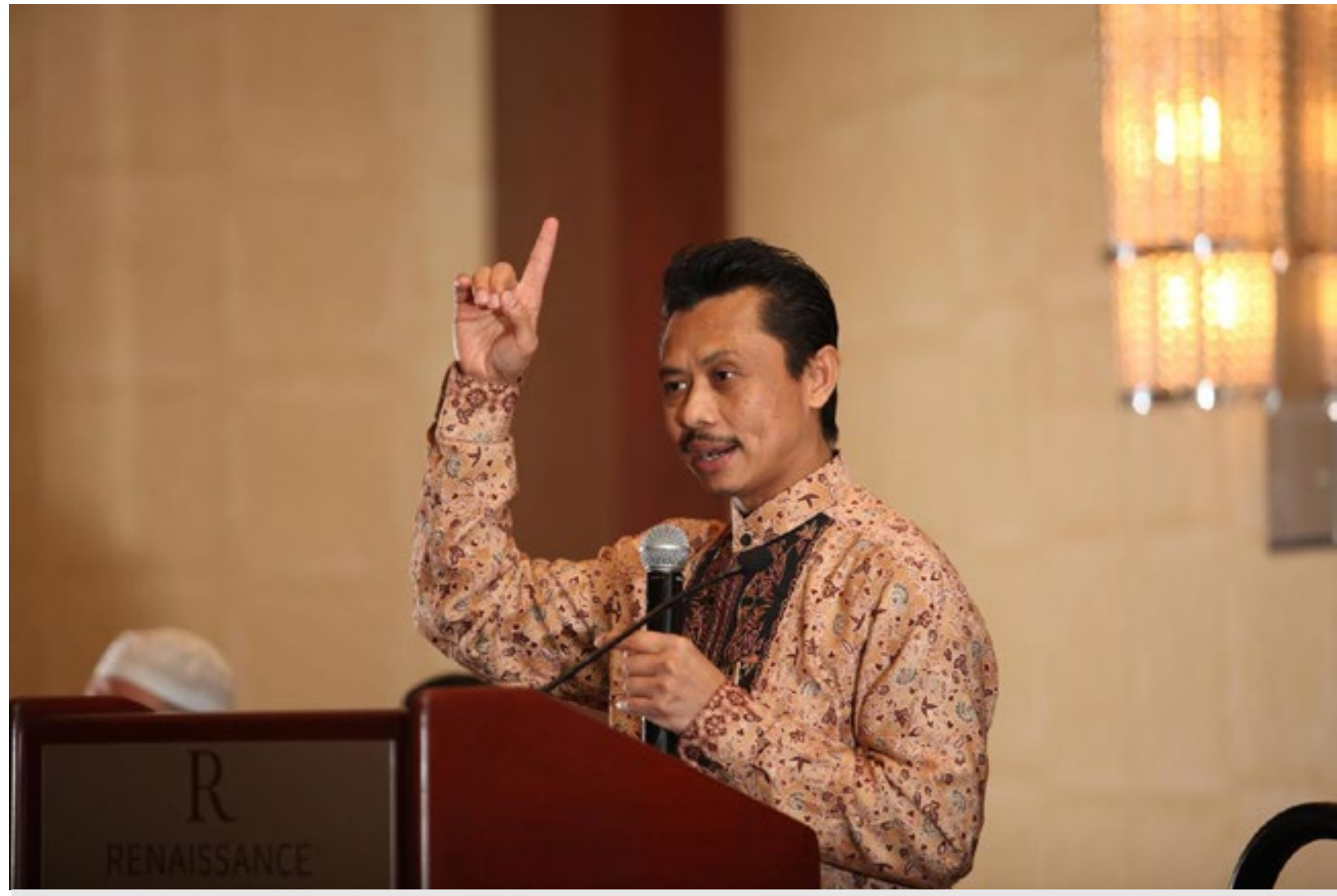

Imam Shamsi Ali

Imam Shamsi Ali is an Islamic scholar and former Imam of the Islamic Cultural Center on 96th Street in East Harlem, New York City's. ${ }^{1}$ He is Chairman of the AlHikmah Mosque in Astoria and the Director of Jamaica Muslim Center in Queens. Ashley Makar interviewed him for MAVCOR in December 2010, during his time as Imam of the 96th Street Islamic Cultural Center.

Ashley Makar: Have you had any arts education?

Imam Shamsi Ali: Yes, arts education is one of the subjects that we learn when we're studying in the Islamic school. In fact, it is a very very important subject because art is a wide subject. It deals with the Qur'an, because when you read the Holy Qur'an you have to read beautifully and that involves art. Also calligraphy, we're learning how to write beautiful writing. We're learning art-it depends on what kind of art you're asking about.

Ashley Makar: So you learn to say the prayers in Arabic and to do the calligraphy?

Imam Shamsi Ali: Yes. 
Ashley Makar: Did you do that education in Indonesia?

Imam Shamsi Ali: Yes.

Ashley Makar: And this part of your professional training?

Imam Shamsi Ali: Yes, it's part of it, because one of the requirements for someone to be a future Imam is that not only are able to read the Qur'an but you are able to read the Qur'an in the best sense of it. You try to beautify your voice as much as you can. It's somewhat like when you want to be a professional singer, you have to train yourself to sing. In fact the Prophet Muhammad said that the person who is able to sing the Qur'an but doesn't sing it is not following my way. The person who has a beautiful voice but simply doesn't want to read it beautifully is ignoring the example of the prophet. And so, we learned how to read holy books in a beautiful voice, in beautiful tones. And it's a part of the things that we, Imams are trained to do. ${ }^{2}$

Ashley Makar: And would you consider this as part of your theological education also?

Imam Shamsi Ali: It's a part [of theological education] because it is grounded in the teaching of the prophet and, when you talk about religion, everything is either related to the Qur'an or the Prophet. When you find any practice that is justified by the prophet's teaching we consider it a part of our religious training.

Ashley Makar: And have objects and/or images played a part in your training?

Imam Shamsi Ali: Yes, for example, when we come to some ritual practices, to make it easier for Muslims to do prayer for example, or hajj pilgrimage. It's easier for our teachers to teach us how to do hajj by using some visual or audiovisual things. For prayer for example, how to stand, how to move the hands, how to bow, how to prostrate, certainly visual things are easier as effective tools of learning.

Ashley Makar: Like videos?

Imam Shamsi Ali: Yes, videos, or pictures also, are sometimes used by the teachers. It is recommended in fact, because, especially for young kids, that one is more effective to keep them remembering. That one is affecting the memory even more.

Ashley Makar: More so than to imitate another person who's doing the prayer?

Imam Shamsi Ali: Not necessarily, but we need to see something visual. Either it is in person or maybe in pictures or in videos. Instead of just explaining it by words, it might be very difficult for the learners to understand.

Ashley Makar: And was this part of your personal training? 
Imam Shamsi Ali: Yes, it's a part of it.

Ashley Makar: And in leading services, do you consider what your wear as a set of aesthetic choices?

Imam Shamsi Ali: First of all, it's not about what I think, it's about where Islam stands on the outfit of the ritual leaders, prayer leaders for example. Should I have this on [what I'm wearing], for example, it's kind of a robe. In fact, if you come to Islam we don't have any justification for all these. I'm [wearing this robe] because I'm leading some Middle Eastern people so I am culturally sensitive. I respect them culturally and I want to make myself a part of them, a part of their community, a part of the congregation, so I don't have to be seen as a strange person. But when I'm leading other communities that belong to certain [other] cultural and ethnic backgrounds, I may dress differently. It depends. This is my daily life, I'm leading Indonesian people with this [outfit], I don't have any problem.

Ashley Makar: In the prayers?

Imam Shamsi Ali: In the prayers there's no problem, because there is no [required] religious dress, there's no [required] Islamic dress, or even Imam's dress or sheikh's dress whatever, there's no such. The point is that, what Islam says about that particular issue-if it says you have to, that's religiously accepted. If Islam doesn't say it, it means it's not religion, and so, all practices that we follow in Islam must be based on a solid ground of religious teachings whether that is the Qur'an or the Prophet's teachings itself. I don't find any explanation in the Qur'an or the Prophet's statements saying that you have to have this on when you lead the people in prayer, so I came to the conclusion that I don't have to, it's religiously not required. I don't feel that it's a must. It depends on which community I'm leading, depends on which culture those people behind me follow, and being a leader, I'm sensitive to the mindset of the people. If they are Arabs I normally dress Arabic, if they are Pakistanis or South Asians, I normally dress South Asian, because as a leader we want to make ourselves a part of the community.

Ashley Makar: In what ways do you address spaces and movement in worship? I understand for Islam there are prescribed ways of prayer that may not apply to other religious groups.

Imam Shamsi Ali: First of all, prayer in Islam, even the name itself in Arabic, is very unique. We call that al-salat in Arabic and the root of the word means connection, relationship. That is the representation of spiritual connection and relationship with God. So when you pray, that represents an intimate relationship or connection with the Almighty God. It is a very comprehensive connection: physical, spiritual, and mindset or intellectual. The whole being basically, physically, materially, spiritually, intellectually, is involved in the prayer. And that's why we have movements, physical movements, and we have reading certain [passages], we have memory, remembrance, as a part of the intellect, but there is emotion, feelings involved as well, and these are spiritual things. 
When we start praying, the first thing that we do is some cleansing, that is what we call wudu or ablution. Normally we wash our hands, cleansing the mouth, and then the face, arms, wiping the head with water, and then washing the feet. All these are symbolizing purification, in and out, physical and spiritual purification, before facing God. Then when we start praying, we raise the hands, certainly for some Muslims it's understood as a symbol of submission to God, the Almighty, surrendering completely ourselves and our will to God and saying Allahu Akbar, God is Great. At that moment, it means you [do not] consider anything else but God. In the language of some Sufi, a spiritual part of the Islamic community, that is the beginning of unifications, it is the beginning of unifying or unity with the Supreme Being, unity with the Divine Being. In that moment, there is a very strong personal connection with God, there is no barrier anymore between us and God. This is why we say Allahu Akbar.

And then we read some portions from the Holy Qur'an, and it involves intellectual exercising, where you remember your God but also your heart is fully aware of the Divine. Then bowing is a symbol of humbleness, praising God, we humble ourselves and then we prostrate down to the ground as a symbol of thankfulness, further humbleness to the Almighty God. But, to directly go to the end of the prayer itself, we sit down in the end as a symbol of humbleness to each other, and then facing to the right and left, saying [to the right] salaam alaikum, may peace and blessings of God be unto you and then to the left, may peace and blessings of God be unto you. All these represent the holy concept of life itself, that in our prayer, we represent all aspects of human life, materially, physically, and intellectually, and also the spiritual way part of life. It's very comprehensive.

Ashley Makar: Do any of the mosques that you serve specifically address issues of art in worship?

Imam Shamsi Ali: Yes, certainly. And that's why for example, before we pray-Friday congregation with prayer, before we start the ceremony, in some mosques they have this Qur'anic reading, a beautiful recitation. These are the best ever recital that we have. We ask them to read the Qur'an for thirty minutes, for twenty minutes, just to be able to listen to the beauty of the Qur'an reading. And then the person who calls to prayer is supposed to have the best, most beautiful voice because calling to the prayer in itself has a certain sort of art involved. Also, in the mosque itself, with calligraphy around ... you know, we don't have that physical images of the Divine in the house of worship, but we have some calligraphy. That gives you a sense of spirituality, when you see readings or writings of the Qur'an or names of the Lord or some others that gives you a sense of closeness to the Divine. We discuss that a lot in our community.

In fact, in some communities they have certain visual things that they consider as tools for them to help form the connection with God, although in some other communities, they consider that innovation. They consider that unacceptable because the Prophet Muhammad didn't do it. But the discussion is there. Some Muslims say Prophet Muhammad didn't do it because at that time probably he was not in need of it. Now we have a lot of distractions around, and it is difficult to have the remembrance of God 
without any sort of-take for example musical instruments. Some Muslims, especially those inclined to the Sufi ways of Islam, use instruments in their remembrance of God. In north Africa, or in some African countries, they use musical instruments as a tool in remembering God. In Saudi Arabia it forbidden: they try to do everything literally as from how Muhammad did it. They criticize those practices as innovations, but there are discussions about this.

Ashley Makar: And how do you understand the arts to be resources for your leadership of religious communities? I'm speaking of the arts broadly.

Imam Shamsi Ali: I think it is very important. I'm of the view that, for example, creating a movie right now for the Muslims, in order to tell about themselves, tell Americans about themselves, is very, very crucial.

Ashley Makar: To represent Islam for non-Muslims or a movie for Muslims?

Imam Shamsi Ali: A movie for non-Muslims and Muslims alike, because 90\% of the movies that [represent some kind of] Islam are certainly negative. I think it's almost $100 \%$, always there's negative about it. Whenever you find anything about Islam in any movie, you'll find mostly negative and so I encourage Muslims to get involved in that particular area, either to be an actor or a producer so that they can normalize and neutralize the misconceptions that we have within the Hollywood world.

I encourage the Muslims to learn music. To use music for example, as an instrument to attract especially the young to come to the House of God. Not at the time of worship, because certainly there is a consensus among the Muslims not to use any instrument when you pray to God, but on certain times when you have, let's say, an event, then you have Islamic songs, people call it nashid ${ }^{3}$ today, and use some instruments. Certainly, for some Muslims, they consider that is not allowed, but in my own understanding it depends on what kind of music you're talking about. There's some music around that may mislead, misleading the young generation to be violent or whatever. But there are some music you may use to remind you about God. It depends on which kind of music [you listen to]. I don't see music as unlawful, so I encourage Muslims to participate and to direct music in the right way, I mean the right way where it is beneficial to humankind, not destructive. Also, we encourage Muslims to participate in the art of writing.

Ashley Makar: Calligraphy?

Imam Shamsi Ali: Calligraphy and also writing itself is an art. And we have here a sister, a lady, who is teaching Muslims how to write articles. It is an art. Also public speaking, public speech, is an art itself, so we are very much involved in art in general.

Ashley Makar: Talking about film, are you actually involved in a film that's being produced about Islam or you're just saying that you encourage Muslims to do acting? 
Imam Shamsi Ali: I myself am involved in two movies so far right now, one is a movieTurkish basically, the producer, but he made a movie in English called "Fight Minorities in New York City."

Ashley Makar: Fight Minorities in New York City?

Imam Shamsi Ali: Yes, it's a documentary. The other one was from California. It also talks about the general misconception that whenever you have a Muslim community, specially immigrants, you will find a lot of extremists. We're saying that this is not necessarily true at all. That might be happening somewhere but it's not necessarily true in all communities so we created that movie. But in general, I encourage the Muslims to learn filmmaking and to get involved in writing, for example writing movies. All these are important.

Ashley Makar: And how do images, objects, the arts and/or sensory experience relate to your leadership?

Imam Shamsi Ali: You know, for me, everything should be seen based on what the teaching itself says or regulates. For example, when it comes to the Divine, certainly it is a [commonly held] agreement in Islam that the Divine is not allowed to be put into any physical image, whether it is God or angels. There are some people making up images about the angels, but I don't know how they came to the conclusion that this is the face of an angel or this is the form of how the angel looks like or whatever.

Ashley Makar: Muslims are making representations of angels?

Imam Shamsi Ali: You know, unfortunately, [some] people even though they are Muslim are very much influenced by some other teachings. There are some Muslims who make pictures of the angel who accompanied Prophet Muhammad to the heavens. The angel is [shown as] a beautiful faced woman with a body that looks like a horse. That is a remnant of the pre-Islamic belief in Arabia which says that angels look like beautiful ladies. That's something that we don't have in our teaching but some people are ignorant and they just make this kind of visual thing which is wrong. Also some people are influenced by their neighbors. In some Muslim countries where they are neighbors with Christians and the Christians have images of God, some of those [Muslims] also try to create something which absolutely in Islam is not allowed. For us one of the reasons why God is not allowed to be put in physical images is because the physical image itself represents limitations. Whatever that image is all about, when you see it as human, that human is limited by race or gender or skin color or whatever. And so, we prefer to limit anything [visual] associated with God because we believe God is unlimited. That's why we don't try to put God in a physical image.

But, for me, I don't feel any obstacles if I follow this particular law because there are some images that we can use, like images of praying people. It is easier for us, for our children to learn how to pray, it's easier for us to teach them how to do haj or pilgrimage in Mecca [with images]. We need some images, but when it relates to the 
Divine it's absolutely not allowed. Not only to the Divine, but even to some individuals or personalities that might be considered very respectful, such as prophets. Muhammad is not allowed to be put in physical images. Islam doesn't allow Muslims to put Jesus in physical images. Any people that we consider very respectful, very beloved to us, such as Moses, Abraham, David, Solomon, Jesus, Muhammad, we are not allowed to put them into physical images. And the reason behind that is because of the law and then the respect. If we are strong and we are knowledgeable all the time about the religion, there's a guarantee that we won't worship them, but if a generation comes that doesn't understand the rules of the religion, they may consider them as the Divine. That's the dilemma.



An example of the kind of work to which Imam Shamsi Ali is referring. An Indian depiction of Muhammad's steed, Buraq, ca. 1660-80

Ashley Makar: In your congregation, what roles have images, objects, or sensory experience played in worship?

Imam Shamsi Ali: I don't know how to answer this one because we don't have any images in the worship itself, I mean, there's no visual at all.

Ashley Makar: It could be either objects or sensory experience.

Imam Shamsi Ali: You know, to be honest, we don't have that except that when the people 
perform hajj, they directly see the Kaaba, and when we pray we face the Kaaba so it's the direction [we face when] praying to God. When they're there, when they're in the area [of the Kaaba], they directly see the Kaaba and I think that direct sight itself gives them more of a sense of spirituality. But in the general services, in general prayer, it doesn't increase or decrease our remembrance of God when we pray.

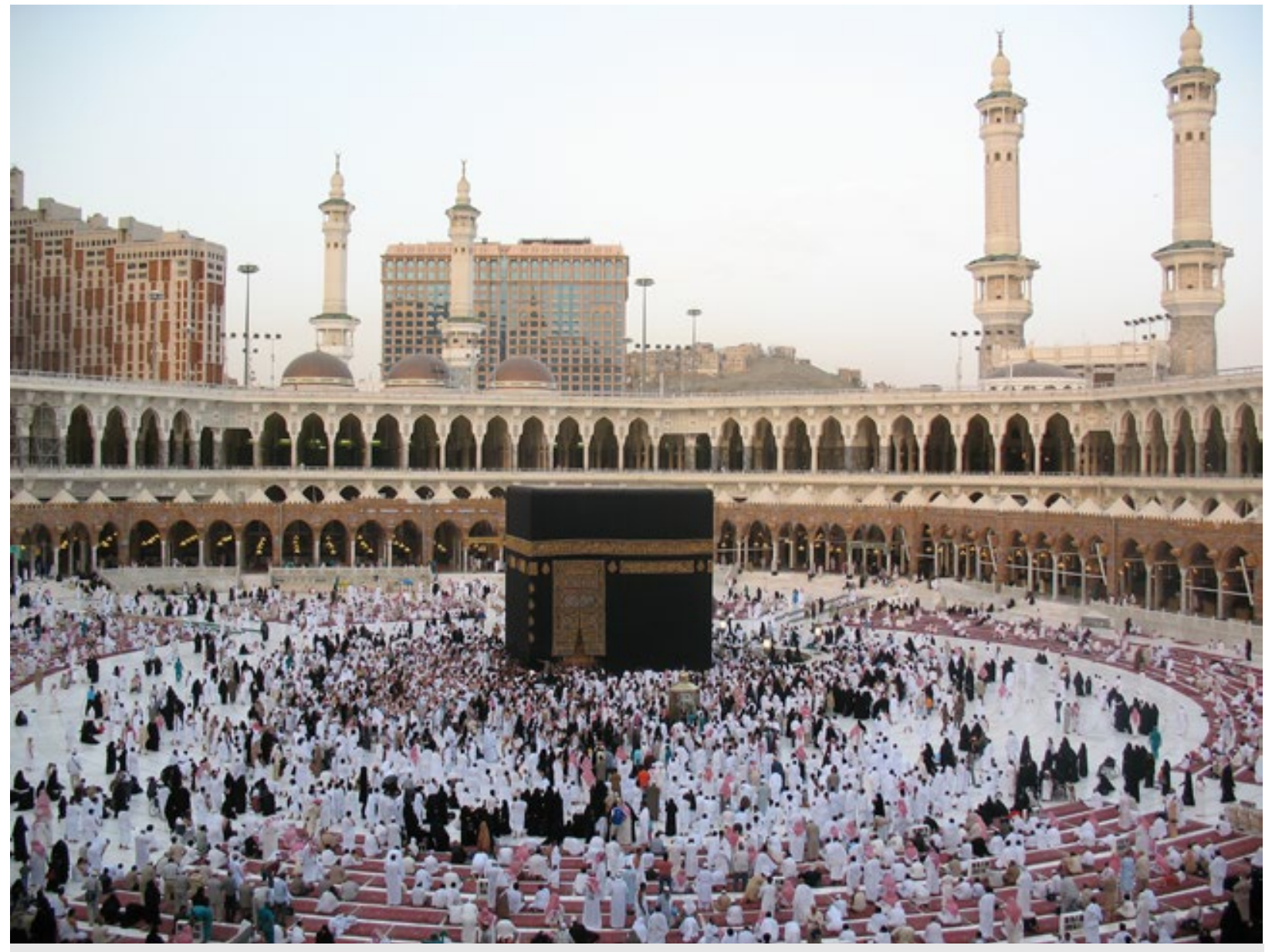

The Kaaba at Mecca with pilgrams

Ashley Makar: What about hearing?

Imam Shamsi Ali: Hearing is also involved because certainly when the Imam reads the Qur'an and he has a more beautiful voice maybe he's more attractive than the less beautiful voice. But you are talking about the visual.

Ashley Makar: Not just visual, I'm also speaking of other senses like smell, hearing.

Imam Shamsi Ali: Yes, all these are helpful, except visual, because again, we don't put the Divine in any visual form, but when you talk about other senses, like listening or hearing or smelling, probably. Muslims love this perfume that comes from the Middle East and there are certain perfume that are really very strong, I think that [they bring with them] the memory of the Kaaba and all these spiritual places. And so, certainly it's helpful. 
Ashley Makar: What is your religious background? Were you raised a Muslim?

Imam Shamsi Ali: My parents are Muslims, and so I do believe that they taught me how to be a Muslim and believe in Islam, but one thing I have to mention is that I'm Muslim not because of my parents, not because I was born Muslim. In our belief as Muslims, everyone is born inclined to worship God, inclined to believe in God. It is later on, because of the circumstances, or the environment surrounding them that makes them someone else. Whether are they Muslims, Christians, or Jews, it is about the environment where you grow up. But in the beginning, all souls of human beings are inclined to the same direction, that is to believe in one God and to humble themselves to God. So that is basically my background.

Ashley Makar: Please discuss any image, any encounters you've had with objects or images in your religious practice, particularly in your childhood. Is there anything you remember specially?

Imam Shamsi Ali: You know, a wrong way of teaching kids in some Muslim countries is that they make the kids kind of scared, so sometimes the parents they read to us about life after death and they show us fire and they say, "If you don't pray, you will be thrown into this fire." Or some scary animals in hell, that they say, "If you don't pray, you will be attacked by these animals." That basically is the images that came to our minds when we were small in the villages because of the ignorance of the parents, they never learned what Islam is all about and how to educate kids on religion. They used these kinds of images to push, not to encourage, but to force kids to pray.

Ashley Makar: And they actually use images, physical images, or just spoke of these?

Imam Shamsi Ali: Sometimes through speeches, sometimes through physical images. There were some books around, comics for example, they have [representations of] fire, they have people that are punished there, and they show you that if you don't do this, you will be here, this will be the consequence. Certainly, for the kids, that might be effective at that moment, but when they grow up and they use their minds, they'll say religion is scary and so that it's kind of a burden, it's difficult. This is the wrong way to educate kids. Prophet Muhammad didn't do it that way.

Ashley Makar: Can you discuss any objects and/or images that you consider of spiritual significance that are found in your home? Your home now, not necessarily from your childhood.

Imam Shamsi Ali: I have in my home now a lot of calligraphy. Qur'anic verses and also some hadith ${ }^{4}$ of the Prophet Muhammad's statements that we put on the walls. That reminds us about the words of God and the teachings of Prophet Muhammad. And there are some pictures of the Kaaba at home and pictures of the mosque which also reminds you to be closer to God as much as you can. So I think there's a spiritual influence in those pictures. 


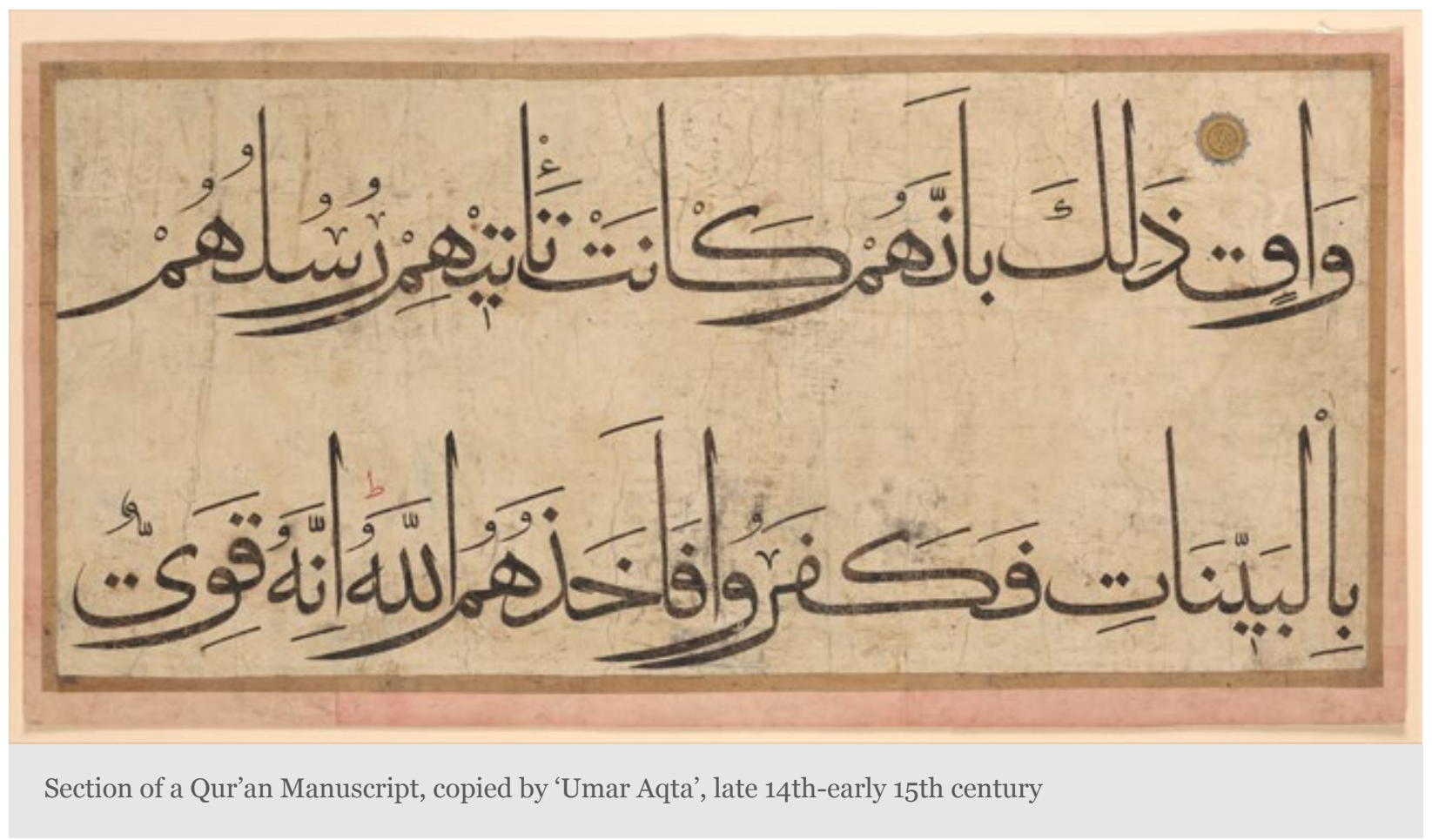

Ashley Makar: What about in the mosque?

Imam Shamsi Ali: In the mosque also. We have some mosques that have a lot of calligraphy. There are some mosques that have a lot of pictures of the Kaaba, but certainly no mosque ever has any picture of the Divine or even Prophet Muhammad.

Ashley Makar: In the lives of an individual or community engaged in religious practice, which objects or images do you think are most prevalent and meaningful?

Imam Shamsi Ali: You know, it depends on the individual because we don't have that any general rule [as to what objects are most influential]. Some people, when they see the picture of the Kaaba, they really remember God because this is where the face turns when people pray. Wherever you are, you turn your face in that particular direction to pray to God, whether it's in the east, west, north, or south, you face that direction. So when you see the Kaaba, that reminds us about God. I think that one is, for some, not for all, more influential, more effective in reminding the people about the Divine, about God. For others it is about reading writings of the Qur'an, looking into the words of God, looking to God himself, speaking to us. For others, pictures of historic places such as Jerusalem or the Prophet's Mosque in Medina and others, all these are images that can remind you about the teaching itself.

Ashley Makar: What role does physical space, either interior space or outdoors, play in your religious or spiritual practices?

Imam Shamsi Ali: For us Muslims, everything else can be the source of spiritual strength. It depends on how do you exercise your understanding and spiritual connection to 


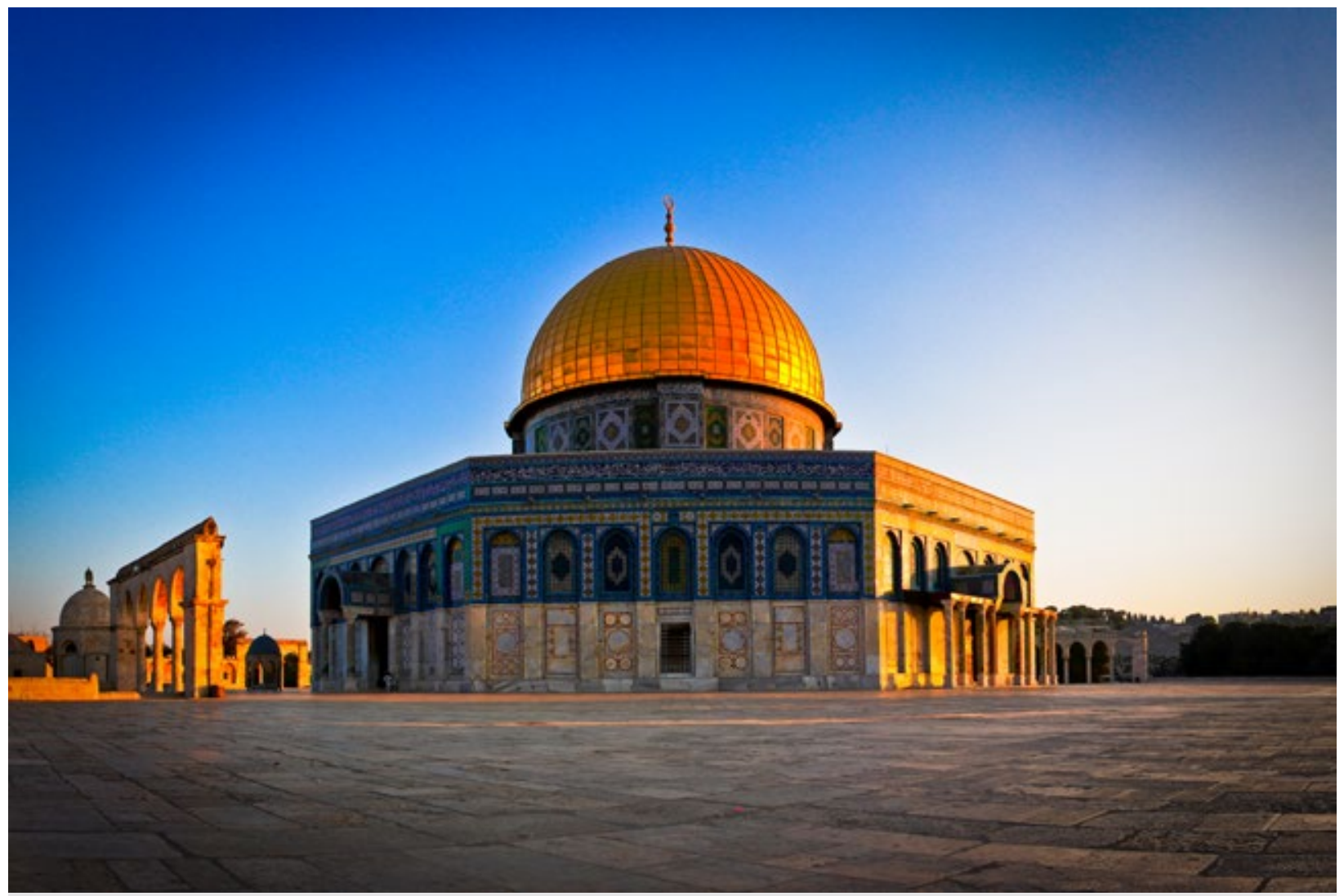

The Dome of the Rock, Jerusalem

things. For example, when I'm in the mosque and I'm sitting down, it's not only sitting, I feel that I am spiritually humbling myself to God. When I enter into the mosque and I take off my shoes, it's not a physical exercise, it is about respect. I feel like I'm in the house of God so I need to respect the house of God. As God says in the Bible, "Take off your sandals." I sense that we are in the presence of God [when I am there] in the mosque. When I'm outside [of the mosque as well] and I see all the creations of God: mountains, seas, and stars, that reminds me of God Himself. When you see the creations, you are basically required to remember the creator. That's why Muslims are encouraged to go do picnics, for example, it's not only for the physical enjoyment but also for the spiritual learning. Either inside or outside, when it comes to the visual things, that impacts your spirituality.

Ashley Makar: Is there anything else you would like to share about these topics, either your personal experience or just about the importance of this among congregational life among Muslims?

Imam Shamsi Ali: When I did hajj the first time in 1991, that was the first time ever I entered into the Grand Mosque in Mecca where the Kaaba is located. I was sitting down and looking at the Kaaba and I was tearing up, I was feeling a spiritual experience that I cannot describe because of that view. For many years I have worshiped God facing that particular direction and now I am here in front of the Kaaba. That image itself has a big impact on my spiritual experience. I think that image itself has certain influences on the 




The Prophet's Mosque in Medina

way people are growing spirituality.

Ashley Makar: And finally are there any other directions in which you would like to take this kind of conversation?

Imam Shamsi Ali: Not really, but in my own view some Muslims are very rigid in how they see the concept of images and visual things in the religion. Now for example some Saudi scholars consider that having human images itself is not allowed. That, for me, is a wrong understanding, because the reason why it was prohibited to have human representations is because, at that time, the time of the prophet, pictures were really influential in the spiritual being of people, people were easily trapped into worshiping 
images. At this time that doesn't happen anymore. I think this discussion should take place. And so there will be some discussion on images in Islam.

Ashley Makar: Thank you very much.

(C) Ashley Makar

\section{Citation Guide}

1. "Imam Shamsi Ali: Thoughts on Islam and Material Culture," by Ashley Makar, Interview, in Conversations: An Online Journal of the Center for the Study of Material and Visual Cultures of Religion (2014), doi:10.22332/con.int.2015.2

"Imam Shamsi Ali: Thoughts on Islam and Material Culture." By Ashley Makar. Interview. In Conversations: An Online Journal of the Center for the Study of Material and Visual Cultures of Religion (2014). doi:10.22332/con.int.2015.2

\section{Notes}

1. For more information about Imam Shamsi Ali, see http://www.bbc.com/news/ magazine-24468337

2. You can watch and listen to video recordings of Imam Shamsi Ali singing the Tafsir of Ar-Rahman on his website: http://shamsiali.com/videos/

3. Nashid refers to Islamic religious song.

4. Hadith are sayings or teachings of the prophet Muhammad preserved in the form of oral tradition by his followers and later written down.

5. This could be a reference to a number of different Biblical passages. See for example Exodus 3:5 and Joshua 5:15, in which God commands Moses and Joshua, respectively, to remove their sandals as they are standing on holy ground.

\section{Yale}

Copyright 2016 Yale University All rights reserved. 